\title{
Change in Size of Tibial Osteoblasts in Embryonic Chicks Treated with Parathyroid Hormone
}

Yasuyuki KanNan and Jun Kanda Faculty of Agriculture, Kobe University, Kobe-shi 657

(Received July 24, 1984)

It has been shown that parathyroid hormone (PTH) is a major physiological regulator of bone resorption and stimulates the release of calcium from bone ${ }^{11}$. The administration of PTH to adult chickens ${ }^{2)}$ or newly hatched chicks ${ }^{3)}$ produces an elevation in the serum calcium concentration. With regard to embryonic chicks, exogenous PTH causes hypercalcemia in 15-day-old embryos ${ }^{4}$ and increases the release of calcium from bones of 12 - or 13 -day-old embryos in organ culture ${ }^{5,6}$. Thus it is more likely that PTH stimulates the osteoclastic bone resorption during the second half of incubation. To our knowledge, however, the effects of PTH on the osteoblasts in the woven bones of embryonic chicks have received little attention.

The present study was undertaken to examine the change in the size of periosteal osteoblasts in the embryonic chick tibia in response to exogenous PTH.

\section{Materials and Methods}

Twenty-four 18-day-old White Leghorn embryos were used in this study. Four each of the embryos were killed $30 \mathrm{~min}, 1,2,4$ and $8 \mathrm{hr}$ after a single injection of $10 \mathrm{U}$ synthetic human PTH (fragment 1-34; Toyo Jozo Co.) into the air space. The rest of the embryos were injected only with saline as controls.

The mid-diaphyseal portion of the left tibia was removed from each embryo and fixed in $4 \%$ paraformaldehyde in $0.1 \mathrm{M}$ phosphate buffer ( $\mathrm{pH} 7.4$ ) for $24 \mathrm{hr}$ at $4{ }^{\circ} \mathrm{C}$. After postfixation in $2 \%$ osmium tetroxide for $2 \mathrm{hr}$, the tissues were dehydrated in ethanol and embedded in JB-4 methyl methacrylate resin (Polysciences, Inc.). Cross sections were cut at $1 \mu \mathrm{m}$, stained with methylene blue and azure II and photographed at $\times 1,000$ magnification.

Histomorphometric analyses were performed by means of a planimeter on photographic prints. The sectional area of each osteoblast facing the bone surface was recorded as an index of the cell size, and evaluated as a morphological response of the cell to PTH.

上皮小体ホルモンを投与されたニワトリ肧子における脛骨骨芽細胞の大きさの变化：河南保幸・荻田

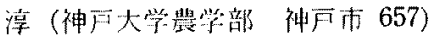




\section{Results and Discussion}

Histomorphometric data obtained in the present study were shown in Fig. 1. The mean value of the sectional areas of osteoblasts from controls was $20.6 \mu \mathrm{m}^{2}$, though there was considerable variation in the cellular areas of cross section measured in this study. A slight decrease in the cellular areas was detected as early as $30 \mathrm{~min}$ after PTH treatment. The maximal effect was seen at $1 \mathrm{hr}$ and the mean value decreased to approximately $70 \%$ of the control. This change was associated with a progressive increase in the number of small osteoblasts, ranging from 2.5 to $12.5 \mu \mathrm{m}^{2}$. However, the cellular area had recovered almost to the control value at $8 \mathrm{hr}$.

The results of the present study demonstrate that an elevation in circulating PTH level in the embryonic chick produces a more rapid and remarkable decrease in size of osteoblasts. Volpi et al. ${ }^{7}$ have pointed out that the decrease in size of the osteoblasts is accompanied by a decrease in the thickness of the underlying osteoid seam, an indicator of the bone matrix deposition rate, in the developing chick tibia. KUSUHARA $^{8)}$ has stated that osteoblastic bone formation in the chicken medullary bone is inhibited immediately after the administration of PTH, based on the alterations in fine structure of the osteoblast. An autoradiographic observation using biologically active ${ }^{125} \mathrm{I}-\mathrm{PTH}$ has shown a concentrated labeling over the cell membranes of osteoblasts in the embryonic chick calvaria ${ }^{9}$.

It is probable that PTH acts directly on osteoblasts to decrease the cell size and to inhibit the formation of the bone matrix.

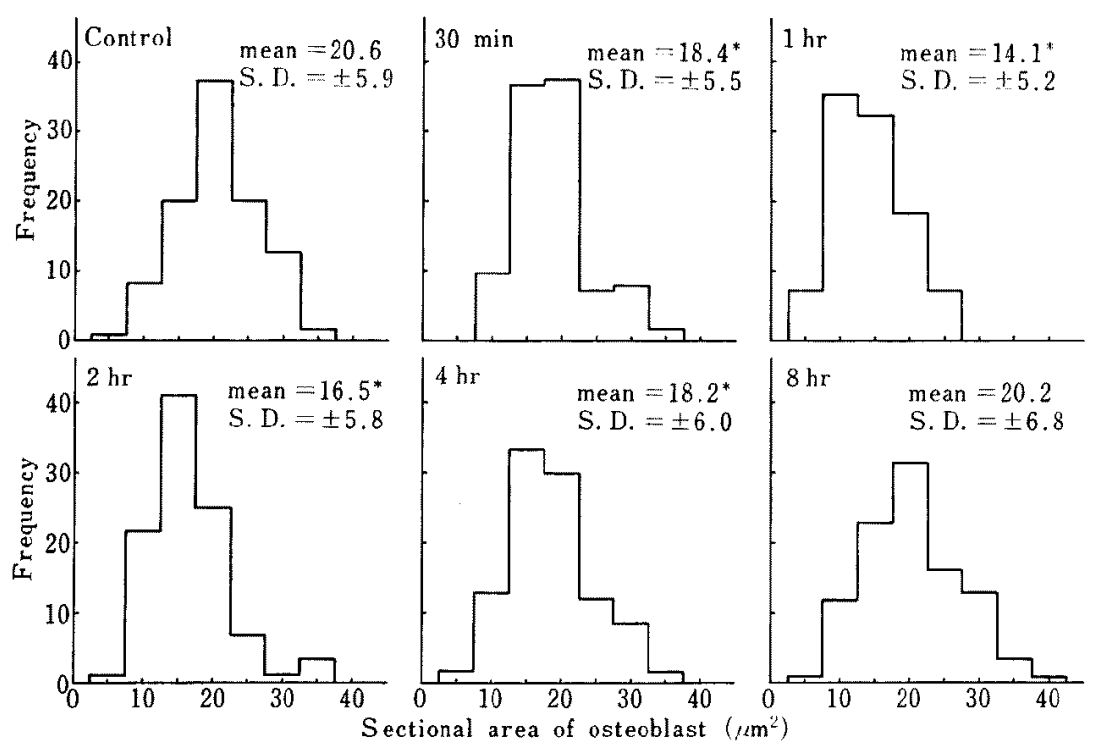

Fig. 1. Changes in the sectional areas of osteoblasts in the embryonic chick tibiae after a single injection of PTH. The frequency in each histogram is expressed as a percentage $(n=200) . \quad{ }^{*}$ Significantly different from control, $P<0.01$ 


\section{KANNAN and KaNDA}

\section{References}

1) DACKE, C. G., Calcium Regulation in Sub-Mammalian Vertebrates. 74-76. Academic Press. London. 1979.

2) Polin, D., P. D. Sturkie and W. Hunsaker, Endocrinology, 60: 1-5. 1957.

3) Lewis, P.E. and T. G. Taylor, J. Endocrinol, 53: xlv-xlvi. 1972.

4) Narbaitz, R., Gen. Comp. Endocrinol, 27: 122-124. 1975.

5) Ramp, W. K. and R. W. MCNen,, Calcif. Tissue Res., 25: 227-232. 1978.

6) Rosen, V., G. Laverty and N. B. Clark, Gen. Comp. Endocrinol., 41: 150-155. 1980.

7) Volpi, G., S, Palazzini, V. Cane, F. Remaggl and M. A. Muglia, Anat. Embryol, 162: 393-401. 1981.

8) Kusuhara, S., Jpn. J. Zootech. Sci., 53: 332-337. 1982.

9) Silve, C. M., G. T. Hradek, A. L. Jones and C. D. Arnaud, J. Cell Biol., 94: 379-386. 1982. 